\title{
Soup kitchen users' social representations of healthy eating associated with their household food security status
}

\section{Representações sociais de usuários de restaurantes populares sobre alimentação saudável associadas à sua condição domiciliar de (in)segurança alimentar}

Isabel Cristina BENTO ${ }^{1}$

Fernanda Martins SOBRINHO²

Mery Natali Silva ABREU ${ }^{3}$

Maria Flávia GAZZINELLI ${ }^{3}$

Simone Cardoso Lisboa PEREIRA ${ }^{4}$

\section{A B S T R A C T}

\section{Objective}

To verify whether what users of soup kitchens in Belo Horizonte, Minas Gerais, Brazil, think about a healthy diet and the challenges they face to eat healthy are associated with their household food security status.

\section{Methods}

This cross-sectional study included 1,656 users of soup kitchens in Belo Horizonte. Socioeconomic and household food security data, and healthy-eating discourses were collected by a semi-structured questionnaire. The data were submitted to descriptive analyses for constructing frequency distribution tables, and to univariate analysis. Discourse analysis was based on the social representation theory.

\section{Results}

To cut, reduce, avoid, not eat, eat less, and decrease carbohydrates, salt, meats, various beverages, and other foods are the most frequent changes $(71.4 \%)$ that food-secure users have made or intend to

${ }^{1}$ Universidade Federal de Minas Gerais, Escola de Enfermagem, Programa de Pós-Graduação em Enfermagem. Belo Horizonte, MG, Brasil.

2 Universidade Federal de Minas Gerais, Escola de Enfermagem, Curso de Gestão em Serviços de Saúde. Belo Horizonte, MG, Brasil.

3 Universidade Federal de Minas Gerais, Escola de Enfermagem, Departamento de Enfermagem Aplicada. Belo Horizonte, MG, Brasil.

4 Universidade Federal de Minas Gerais, Escola de Enfermagem, Departamento de Nutrição. Av. Prof. Alfredo Balena, 190, Santa Efigênia, 30130-100, Belo Horizonte, MG, Brasil. Correspondência para/Correspondence to: SCL PEREIRA. E-mail: <simoneclpereira@gmail.com>. 
make. Food-insecure users intended to eat more fruits, non-starchy vegetables, and other foods (34.4\%). The main obstacles food-secure and food-insecure users face to adopt a healthier diet are lack of time $(82.9 \%)$ and low income $(53.5 \%)$, respectively $(p<0.001)$.

\section{Conclusion}

What users of soup kitchens in Belo Horizonte think about food and the obstacles they face to adopt a healthier diet are related to their household food security status. The results provide valuable data for effective proposals of food and nutrition education, which should act on the producers of subjectivity in this group and consider this group's food and nutrition security status.

Keywords: Collective feeding. Food and nutrition security. Food habits. Nutrition programs and policies.

\section{RE S U M O}

\section{Objetivo}

Verificar a associação entre a forma como os usuários dos restaurantes populares de Belo Horizonte, Minas Gerais, pensam sobre alimentação saudável, bem como as dificuldades para adotá-la; e a sua condição domiciliar de (in)segurança alimentar.

\section{Métodos}

Estudo transversal conduzido com 1656 usuários dos restaurantes populares de Belo Horizonte. A coleta de dados, com emprego de um questionário semiestruturado, contemplou a situação socioeconômica, a condição domiciliar de (in)segurança alimentar e discursos sobre alimentação saudável. Realizou-se análises descritivas para a construção de tabelas de distribuição de frequências e análise univariada. A análise dos discursos fundamentou-se na teoria das representações sociais.

\section{Resultados}

Cortar, reduzir, evitar, não comer, comer menos, diminuir carboidratos, gorduras, sal, carnes, bebidas diversas e outros alimentos é a mudança mais frequente $(71,4 \%)$ que os usuários, em condição domiciliar de segurança alimentar, realizam ou pretendem realizar. Já para aqueles em condição domiciliar de insegurança alimentar é comer mais frutas, verduras, legumes e outros alimentos (34,4\%). Para os usuários em segurança alimentar nutricional a dificuldade determinante é a falta de tempo (82,9\%) e para aqueles em insegurança alimentar nutricional é a condição financeira (53,5\%), p<0,001.

\section{Conclusão}

O que os usuários dos restaurantes populares de Belo Horizonte pensam sobre alimentação, bem como as dificuldades para se alimentar de maneira mais saudável, estão associadas à condição domiciliar de (in)segurança alimentar. Os resultados são subsídios relevantes para a elaboração de propostas educativas efetivas em alimentação e nutrição, que atuem sobre os dispositivos produtores de subjetividade desse público e que considere a sua situação de segurança alimentar e nutricional.

Palavras-chave: Alimentação coletiva. Segurança alimentar e nutricional. Hábitos alimentares. Programas e políticas de nutrição e alimentação.

\section{INTRODUCTION}

Nutrition transition is characterized by an increase in the prevalence of overweight and obesity and a decrease in the prevalence of nutritional deficiencies. This phenomenon involves changes in dietary and nutritional patterns, increasing the population's risk of chronic noncommunicable diseases ${ }^{1,2}$.
In the last years, these changes in Brazil were mostly characterized by a high intake of ultra-processed foods, which are high in carbohydrates, fats, and sodium, and nearly free of dietary fibers, and by a low intake of fruits and non-starchy vegetables ${ }^{3}$.

This scenario weakens Brazilians' food and nutrition security, which is understood as the "realization of everyone's right to regular and 
permanent access to adequate amounts of quality foods without compromising access to other essential needs; nutrition security is founded on dietary practices that promote health, respect cultural diversity, and are culturally, economically, environmentally, and socially sustainable" (p.4) ${ }^{4}$.

One of the government's strategies to promote food and nutrition security and reduce the number of food-insecure people is the Programa Restaurante Popular (Soup Kitchen Program). This Program is recognized in Brazil and abroad as a successful public administration initiative, offering meals in large cities at very affordable prices ${ }^{5}$.

Nonetheless, eating healthy is challenging, hindering individuals' motivation to change their dietary habits. Thus, individuals need help to make healthy food choices but to propose interventions that fit their reality, we must know what they think, what they know about food, and the challenges they face to eat healthy ${ }^{6,7}$.

Food practices are influenced by sociocultural desires, meanings, values, attitudes, beliefs, symbols, and experiences located in the sphere of social representations ${ }^{6}$. Knowing individuals' social representations of eating habits may facilitate the creation of interventions that meet their needs, improving their diet ${ }^{5}$. Social representations of eating habits condition food practices ${ }^{6}$.

In face of the above, the objective of the present study was to determine whether what users of soup kitchens in Belo Horizonte (MG) think about a healthy diet and the obstacles they face to adopt it are associated with their household food security status.

By surveying the social representations of this target population, we will learn about their desire to improve their diet and about the obstacles they face to do so, and by determining whether these items are associates with this population's household food and nutrition security status, we will uncover data that will allow planning more effective interventions. Education actions require strategies that directly impact the subjects, allowing them to rethink and recreate their food habits in order to overcome barriers and consequently, eat healthier.

\section{METHODS}

This analytical, cross-sectional study with a qualitative and quantitative approach surveyed male and female adults frequenting all the soup kitchens in the municipality of Belo Horizonte from October 2009 to June 2012.

These restaurants are part of a public social inclusion policy. They cater to a significant portion of Belo Horizonte population, serving fourteen thousand meals a day. These establishments are located in the downtown area of the city, close to mass transportation stations, or in suburban areas where the population is at social and nutritional risk. The following soup kitchens are currently open in Belo Horizonte: Restaurante Popular Herbert de Souza (RPI), Restaurante Popular Josué de Castro (RPII), Restaurante Popular Maria Regina Nabuco (RPIII), Restaurante Popular Dom Mauro Bastos (RPIV), and Refeitório Popular da Câmara Municipal João Bosco Murta Lages (RPV). Establishments RPI, RPII, and RPIV are located downtown, where neighborhoods' Municipal Human Development Index (MHDI) vary greatly. The downtown area is considered a region of low social vulnerability. However, establishments RPII and RPIV are located in neighborhoods with low MHDI and high to extreme social vulnerability 8,9 .

The sample size was established by measuring the weekly flow because there are no records of soup kitchen users, only records of the number of meals sold daily. From this number we calculated the number of users in each of the five establishments as follows ${ }^{10}$ :

$$
\begin{aligned}
& \mathrm{n}_{0}=1 /\left(\mathrm{E}_{0}\right)^{2} \\
& \mathrm{n}=\mathrm{N} * \mathrm{n}_{0} /\left(\mathrm{N}+\mathrm{n}_{0}\right)(2)
\end{aligned}
$$

Where: $\mathrm{n}_{0}=$ an initial estimate of the sample size; $\mathrm{N}=$ population size (mean flow of 
users per day); $\mathrm{E}_{0}=$ sampling error of $5 \%$, and $\mathrm{n}=$ sample size.

The estimated sample size for each establishment was as follows: RPI ( $n=382)$, RPII $(n=380)$, RPIII $(n=240)$, RPIV $(n=331)$, and RPV $(n=280)$, totaling 1,613 users. The calculation took into account the number of users frequenting each soup kitchen that would be representative of each establishment. In addition to calculating sample size, we decided to collect data by quotas, respecting the users' gender and age group distribution and the number of meals sold in each establishment (breakfast, lunch, and supper). This method was used because it was not possible to randomly select the interviewees ${ }^{10}$.

The inclusion criteria were: not to live in a household with another study participant; to be at least 18 years old; to be a regular user of soup kitchens in Belo Horizonte; and to agree to participate in the study by signing an Informed Consent Form. The study complied with the ethical regulations of Resolution $n^{\circ} 466 / 2012$ of the National Health Council11.

The users were interviewed while they waited for the soup kitchens to open. The interviewees were approached randomly but respecting the established gender and age proportions. The interviews were conducted by six trained students from the programs Nutrition and Health Service Management and by a master's student of the graduate program Nursing/Health Education and Nursing. The data collection instrument was tested in a sample of users of one of the food kitchens of Belo Horizonte. This test resulted in the decision to use open questions in the interview because most participants used short discourses to answer the questions and because of the high similarity between the discourses written down during the interviews and the recorded and transcribed discourses, preserving the key expressions and the central ideas of the discourses.

The semi-structured questionnaire collected socioeconomic aspects, gender, age, education level, occupation, socioeconomic class ${ }^{12}$, and marital status. It also contained all the questions in the Escala Brasileira de Insegurança Alimentar (EBIA, Brazilian Scale of Food Insecurity) ${ }^{13}$ and the following open questions: 1) "Have you changed or intend to change your diet?" 2) "How have you changed or intend to change your diet?" (only for those who answered question 1 affirmatively); 3) "Is it hard for you to eat healthier?", and 4) "Why is it hard for you to eat healthier?" (only for those who answered question 3 affirmatively).

Socioeconomic class was classified according to the criteria provided by the 2008 Socioeconomic Survey of Instituto Brasileiro de Opinião Pública e Estatística (Brazilian Institute of Public Opinion and Statistics) ${ }^{12}$.

Food security status was determined by EBIA, validated for Brazil. EBIA estimates the level of food security of a household ${ }^{13}$. The instrument contains 15 closed questions with positive and negative answers regarding the food security level of a household, perceived by the family, in the three months that precede the interview. Each affirmative answer receives one point. The score ranges from zero to fifteen points, where zero represents food security; 1-5 points represent mild food insecurity; 6-10 points represent moderate food insecurity; and 11-15 points represent severe food insecurity. Each main question is followed by a question about the frequency of the event.

To delimit the social representations, the open questions of the questionnaire were digitalized, constituting the discourses. Later, the data were categorized and analyzed according to content similitude and expressed as frequencies. This technique involves selecting key expressions in each individual answer, which are the most significant excerpts of the answer. These key expressions correspond to central ideas that synthesize the content of the discourse. A single category of central ideas was attributed to each discourse, covering all the key expressions ${ }^{14}$.

The discourses were analyzed according to the social representation theory and its sociological suppositions. Social representations are subjectivities that highly influence practices 
and behaviors. Their objective is to abstract sense of the world by introducing orders and perceptions ${ }^{7}$. Moreover, as a particular form of this guiding knowledge, social representations are socially created and shared knowledge forms that contribute to the construction of a common reality, allowing an individual to understand the world and communicate therein ${ }^{15}$.

The data were digitized and organized in the software EpiData (EpiData Association, Adense, Dinamark) version 3.1.2. The statistical analyses were performed by the software Statistical Package for the Social Sciences (SPSS Inc., Chicago, Illinois, United States) for Windows, version 19.0. Descriptive analyses were performed to construct frequency distribution tables, and univariate analysis was conducted to measure the associations between the variables related to the social representations of healthy eating and household food security status. The Pearson's Chi-square test was also used at a significance level of $5 \%$.

The project "Prevalência domiciliar de segurança/insegurança alimentar dos usuários dos restaurantes populares de Belo Horizonte - Minas Gerais" (Prevalence of household food security in users of soup kitchens in Belo Horizonte - Minas Gerais) was approved by the Research Ethics Committee of the Universidade Federal de Minas Gerais under Protocol no 143/09. The project to survey social representations in the same population was approved by the same committee under Protocol $n^{\circ}$ 0473.0.203.000-10.

\section{RE S U L T S}

A total of 1,656 users of soup kitchens in Belo Horizonte participated in the study. Most users were young adults aged 18 to 30 years or adults aged 31 to 49 years. In other words, most users were male, working age, employed, of socioeconomic class C, and had completed high school (Table 1). More than $60.0 \%$ of the users of each establishment were food secure. RPII had the highest prevalence of food insecurity (38.9\%) and RPIV, the lowest (16.9\%).
As for social representations, $52.9 \%$ of the 1,579 users who answered the question, "Have you changed or intend to change your diet?" reported not having changed and not intending to change their diet. However, $65.2 \%$ of the 1,501 users who answered the question, "Is it hard for you to eat healthier?" reported having difficulties to eat healthier. Additionally, when the "type of change that the users have made or intend to make in their diets" and "difficulties to eat healthy" were combined, $83.2 \%$ of the 685 users who had changed or intended to change their diets had difficulties to eat healthy $(p<0.001)$.

Analysis of the central ideas of the "type of change that the users have made or intend to make in their diets" showed that most subjects believed that "cutting, reducing, avoiding, not eating, eating less, and decreasing carbohydrates, fats, salt, meats, various beverages, and other foods" (Table 2) were the changes that they had to make to eat healthier, as exemplified in the discourse below: "I need to cut/reduce carbohydrates and fatty foods to have a healthier diet $^{\prime \prime}$.

The second most common desired change present in the central ideas of the answers was "to eat more fruits and non-starchy vegetables and to avoid/reduce other foods" (Table 2): "I intend to change my diet by eating more fruits and non-starchy vegetables and by consuming fewer deep-fried foods and sweets".

The most common central idea to the answers related to the "difficulties of eating healthy" was "low income", followed by "lack of time" (Table 2) as shown below: "The money I have is not enough to buy healthy foods because they are usually very expensive and my salary is low, so I can't".

The subject believes that income is a decisive component for food acquisition. Furthermore, socioeconomic condition limits the acquisition of foods considered healthy by the subjects, so it is an obstacle for obtaining the desired items: 
Table 1. Sociodemographic profile of users of soup kitchens in Belo Horizonte (MG), Brazil, 2012 ( $n=1,656)$.

\begin{tabular}{|c|c|c|c|c|c|c|c|c|c|c|c|c|}
\hline \multirow{3}{*}{ Sociodemographic factors } & \multicolumn{12}{|c|}{ Soup kitchens } \\
\hline & \multicolumn{2}{|c|}{ RPI } & \multicolumn{2}{|c|}{ RPII } & \multicolumn{2}{|c|}{ RPIII } & \multicolumn{2}{|c|}{ RPIV } & \multicolumn{2}{|c|}{ RPV } & \multicolumn{2}{|c|}{ TOTAL } \\
\hline & $M$ & SD & $\mathrm{M}$ & SD & $M$ & SD & $M$ & SD & $M$ & SD & M & SD \\
\hline \multirow[t]{2}{*}{ Age (years)* } & 44.95 & 16.9 & 44.14 & 17.8 & 43.91 & 17.5 & 40.31 & 16.6 & 37.08 & 12.3 & 42.34 & 16.7 \\
\hline & $n$ & $\%$ & $n$ & $\%$ & $n$ & $\%$ & $n$ & $\%$ & $n$ & $\%$ & $n$ & $\%$ \\
\hline \multicolumn{13}{|l|}{ Gender $^{*}(n=1,656)^{* *}$} \\
\hline Male & 307 & 76.8 & 249 & 62.9 & 196 & 79.0 & 217 & 65.6 & 207 & 73.7 & 1,176 & 71.0 \\
\hline Female & 93 & 23.3 & 147 & 37.1 & 52 & 21.0 & 114 & 34.4 & 74 & 26.3 & 480 & 29.0 \\
\hline \multicolumn{13}{|l|}{$\begin{array}{l}\text { Employment status }^{*} \\
(n=1,646)^{* *}\end{array}$} \\
\hline Does not work & 162 & 40.7 & 177 & 44.9 & 90 & 36.3 & 97 & 29.8 & 39 & 13.9 & 565 & 34.3 \\
\hline Works & 236 & 59.3 & 217 & 55.1 & 158 & 63.7 & 229 & 70.2 & 241 & 86.1 & 1,081 & 65.7 \\
\hline \multicolumn{13}{|l|}{$\begin{array}{l}\text { Socioeconomic class } \\
(n=1,260)^{* *}\end{array}$} \\
\hline Classes A and B & 47 & 16.3 & 55 & 19.2 & 41 & 20.8 & 93 & 34.1 & 75 & 34.9 & 311 & 24.7 \\
\hline Class C & 142 & 49.1 & 158 & 55.2 & 106 & 53.8 & 136 & 49.8 & 120 & 55.8 & 662 & 52.5 \\
\hline Classes $\mathrm{D}$ and $\mathrm{E}$ & 100 & 34.6 & 73 & 25.5 & 50 & 25.4 & 44 & 16.1 & 20 & 9.3 & 287 & 23.8 \\
\hline \multicolumn{13}{|l|}{ Marital status ${ }^{*}(n=1,649)^{* *}$} \\
\hline No partner & 274 & 68.7 & 238 & 60.1 & 137 & 55.5 & 187 & 57.0 & 147 & 52.7 & 983 & 59.6 \\
\hline Has partner & 125 & 31.3 & 158 & 39.9 & 110 & 44.5 & 141 & 43.0 & 132 & 47.3 & 666 & 40.4 \\
\hline \multicolumn{13}{|l|}{ Education level" $(n=1,650)^{* *}$} \\
\hline Elementary school & 178 & 44.8 & 143 & 36.3 & 108 & 43.5 & 95 & 28.7 & 45 & 16.1 & 569 & 34.5 \\
\hline High school & 173 & 43.6 & 179 & 45.4 & 115 & 46.4 & 156 & 47.1 & 170 & 60.7 & 793 & 48.1 \\
\hline Higher education & 46 & 11.6 & 72 & 18.3 & 25 & 10.1 & 80 & 24.2 & 65 & 23.2 & 288 & 17.5 \\
\hline \multicolumn{13}{|l|}{$\begin{array}{l}\text { Household food security } \\
\text { status }^{*}(n=1,656)^{\star *}\end{array}$} \\
\hline Food secure & 275 & 68.8 & 242 & 61.1 & 176 & 71.0 & 275 & 83.1 & 230 & 81.9 & 1,198 & 72.3 \\
\hline Food insecure & 125 & 31.3 & 154 & 38.9 & 72 & 29.0 & 56 & 16.9 & 51 & 18.1 & 458 & 27.5 \\
\hline
\end{tabular}

Note: ${ }^{*} p$-value of Chi-square test $<0.05 ;{ }^{* *}$ Values considering valid data.

RPI: Restaurante Popular Herbert de Souza; RPII: Restaurante Popular Josué de Castro; RPIII: Restaurante Popular Maria Regina Nabuco; RPIV: Restaurante Popular Dom Mauro Bastos; RPV: Refeitório Popular da Câmara Municipal João Bosco Murta Lages; M: Mean; SD: Standard Deviation.

Table 2. Distribution of the number of central ideas found in the answers to the questions about the social representations of a healthy diet. Belo Horizonte (MG), Brazil, 2012.

\begin{tabular}{|c|c|c|}
\hline Central ideas & $\mathrm{n}$ & $\%$ \\
\hline \multicolumn{3}{|l|}{ What type of change have you made or intend to make in your diet? $(n=743)^{*}$} \\
\hline To cut, reduce, avoid, not eat, eat less, decrease carbohydrates, fats, salt, meats, various beverages, and other foods. & 304 & 40.9 \\
\hline To eat more fruits and non-starchy vegetables, and to avoid/decrease other foods. & 177 & 23.8 \\
\hline To eat more fruits and non-starchy vegetables. & 106 & 14.3 \\
\hline $\begin{array}{l}\text { Healthy, balanced, natural, varied diet, high in fibers, eat with moderation, eat at every three hours, drink more } \\
\text { water. }\end{array}$ & 92 & 12.4 \\
\hline To eat more fruits, non-starchy vegetables, and other foods. & 64 & 8.6 \\
\hline \multicolumn{3}{|l|}{ What keeps you from having a healthier diet? $(n=979)^{*}$} \\
\hline Low income. & 374 & 38.2 \\
\hline Habits, customs, food preferences, taste. & 216 & 22.1 \\
\hline Lack of time. & 117 & 11.9 \\
\hline Lack of access, lack of option, lack of information. & 73 & 7.5 \\
\hline Lack of time and other reasons. & 44 & 4.5 \\
\hline Other (central idea excluded). & 155 & 15.8 \\
\hline
\end{tabular}

Note: *Values considering valid data. 
I have no time to prepare/cook and buy healthy foods. This type of food deteriorates frequently, and less healthy foods are more practical. In the day-to-day rush I have all my meals away from home, I work a lot and have no time to look for restaurants that serve healthier meals.

The discourse above indicates that the subject wants practicality, comfort, speed, and safety. The lack of time hinders the search for good alternatives to have a healthy diet.

Univariate analysis measured the association between the variables related to the social representations of a healthy diet and the level of food security of the households of users of soup kitchens from Belo Horizonte (Table 3), and significant associations were found $(p<0.001)$. Food-secure users reported having made or the intention to make the following changes: "cut, reduce, avoid, not eat, eat less, and decrease carbohydrates, fats, salt, meats, various beverages, and other foods". Additionally, most of these subjects $(71.4 \%)$ report that "lack of time" $(82.9 \%)$ is the main obstacle for eating healthier (Table 3).

Food-insecure users more commonly reported that "eating more fruits, non-starchy vegetables, and other foods" was the main change they needed or intended to make, and the most common reason for not eating healthier was "low income" (53.5\%) (Table 3).

\section{DISCUSSION}

The analysis and associations made by the present study are important because they provide data for better planning a food and nutrition education intervention that use healthy dietpromoting strategies that actually meet this group's real needs.

In this sense a proposal of food and nutrition education in consonance with the

Table 3. Association between household food and nutrition security status and the central idea of the social representations of making dietary changes and the difficulties of eating healthier. Belo Horizonte (MG), Brazil, 2012.

\begin{tabular}{|c|c|c|c|c|c|}
\hline \multirow{2}{*}{ Variable } & \multicolumn{2}{|c|}{ Food security } & \multicolumn{2}{|c|}{ Food insecurity } & \multirow{2}{*}{$p$} \\
\hline & $\mathrm{n}$ & $\%$ & $\mathrm{n}$ & $\%$ & \\
\hline \multicolumn{6}{|l|}{ Has changed or intends to change diet $(n=1,579)^{* *}$} \\
\hline Yes & 512 & 68.9 & 231 & 31.1 & \multirow{2}{*}{$<0.001^{*}$} \\
\hline No & 632 & 75.6 & 204 & 24.4 & \\
\hline \multicolumn{6}{|l|}{ Has difficulties to eat healthier $(n=1,501)^{* *}$} \\
\hline Yes & 638 & 65.2 & 341 & 34.8 & \multirow{2}{*}{$<0.001$} \\
\hline No & 428 & 82.0 & 94 & 18.0 & \\
\hline \multicolumn{6}{|l|}{ Dietary changes I made or intend to make $(n=743)^{* *}$} \\
\hline To eat more fruits and non-starchy vegetables & 73 & 68.9 & 33 & 31.1 & \multirow{5}{*}{0.76} \\
\hline To eat more fruits, non-starchy vegetables, and other foods & 42 & 65.6 & 22 & 34.4 & \\
\hline To eat more fruits and non-starchy vegetables and avoid/reduce other foods & 117 & 66.1 & 60 & 33.9 & \\
\hline $\begin{array}{l}\text { Healthy, balanced, natural, varied diet, high in fibers, eat in moderation, eat at every } \\
\text { three hours, drink more water }\end{array}$ & 63 & 68.5 & 29 & 31.5 & \\
\hline $\begin{array}{l}\text { To cut, reduce, avoid, not eat, eat less, decrease carbohydrates, fats, salt, meats, various } \\
\text { beverages, and other foods }\end{array}$ & 217 & 71.4 & 87 & 28.6 & \\
\hline \multicolumn{6}{|l|}{ Difficulties to eat healthier $(n=979)^{* *}$} \\
\hline Lack of time & 97 & 82.9 & 20 & 17.1 & \multirow{6}{*}{$<0.001^{*}$} \\
\hline Lack of time and other reasons & 30 & 68.2 & 14 & 31.8 & \\
\hline Low income & 174 & 46.5 & 200 & 53.5 & \\
\hline Habits, customs, food preferences, taste & 167 & 77.3 & 49 & 22.7 & \\
\hline Lack of access, lack of option, lack of information, other & 53 & 72.6 & 20 & 27.4 & \\
\hline Other (central idea excluded) & 117 & 75.5 & 38 & 24.5 & \\
\hline
\end{tabular}

Note: ${ }^{*}$ Chi-square test; statistically significant values in bold; **Values considering valid data. 
effective transformation of people's attitudes and practices cannot avoid a stance that challenges the linear models of simple information transmission ${ }^{15}$. Consequently, the great challenge is to design a proposal that coordinates the teaching resources that act on the producers of subjectivity using social representations. Moreover, taking into account the target population's social and economic factors is also a challenge $\mathrm{e}^{7,16}$.

The study subjects are working-age workers of low socioeconomic status, characteristics that meet the profile of the desired target population, especially of the Soup Kitchen Program ${ }^{5}$. These data corroborate Gonçalves et al. ${ }^{17}$, who studied users of 19 soup kitchens in five Brazilian state capitals. These users were mostly working-age males (70\%) who had completed high school and whose socioeconomic status was compatible with the proposal of the said Program.

Sociodemographic characteristics are considered conditioners of food habits. Men with low education level and income have low intake of fruits, non-starchy vegetables, whole grains, and lean meats ${ }^{18}$. Additionally, most of the study subjects are nutritionally vulnerable, a fact also reported by Bento ${ }^{19}$, who determined the sociodemographic, nutritional, and psychosocial profile of soup kitchen users in Belo Horizonte. Bento ${ }^{19}$ found a high prevalence of overweight and high frequency of food habits classified as "regular", that is, the individual has a monotonous diet and needs to improve it, in addition to other habits such as inadequate physical activity and fluid intake.

The study data are reinforced by the Family Butget Survey 2008-20093 ${ }^{\text {, Vigite }}{ }^{20}$, and Levy et al. ${ }^{18}$, which found that Brazilians do not consume adequate amounts of fruits and non-starchy vegetables. Furthermore, Brazilians consume too many calories from saturated fats, sugar, and salt, and have low fiber intake. This is concerning because such food habits are associated with some chronic non-communicable diseases.
However, many people are not ready or willing to make dietary changes, and others have difficulties adopting a healthier diet.

Most users in the present study reported not having made or intending to make dietary changes, and a portion of these users do not believe they have difficulties eating healthier, which leads them not to worry about this issue. This fact may indicate that these users may not recognize their bad eating habits, which is one more problem for future food and nutrition education actions to address because they have no motivation to make dietary changes ${ }^{21}$.

The association between having made or the intention to make dietary changes and the difficulty of eating healthier showed that most users who made or intended to make dietary changes had difficulty to eat healthier, which probably denotes their concern with their current diet. On the other hand, this duality may compromise meal quality and increase the risk of health problems ${ }^{7}$, evidencing the need of food and nutrition interventions that consider cultural and economic aspects, as well as habitual life characteristics defined by these individuals to make the desired dietary changes ${ }^{5}$.

The central ideas indicate that users have notions about the recommended healthy eating practices since they mention the practices advocated by the Ministry of Health ${ }^{22}$. Moreover, the central idea about the difficulties to eat healthier involve organizing time and activities of daily living, budget planning, having nearby healthy food outlets, understanding the relationship between socioeconomic level and diet, and desiring to change food habits and try new flavors.

The associations between the type of dietary changes that users have made or intend to make and the difficulties to eat healthier and household food security status showed that food-secure users prefer healthier foods and avoid energy-dense foods, and lack of time is the main obstacle to a healthier diet. These findings corroborate Silva \& Costa ${ }^{23}$, who assessed the characteristics, obstacles, and motivators of fruit 
and non-starchy vegetable intake by adults from Brazilia and found that lack of time is associated with long working hours and low acquisition of fruits and non-starchy vegetables because of their perishability ${ }^{23}$.

Food-insecure users desire to eat more fruits and non-starchy vegetables. However, their low income is the main obstacle that prevents them from doing so, forcing them to eat energy-dense foods because of their higher affordability ${ }^{24}$.

The wellbeing of low-income individuals is at risk because high intake of foods high in fats, sugars, and salt, and low intake of fruits and non-starchy vegetables are not only a risk for chronic non-communicable diseases ${ }^{25}$ but are also associated with food insecurity ${ }^{26}$. Studies have shown that income is the most important determinant of inequity, and income also explains food insecurity because it limits one's ability to acquire healthy and safe foods ${ }^{26-28}$. Nonetheless, other sociodemographic determinants must be investigated, such as household size, education level, race, and basic sanitation, among others ${ }^{29}$.

The study findings, a snippet of the social transformations that impacted Brazilians' health and nutrition statuses, indicate the need of a guideline that promotes an adequate and healthy diet. In this sense, the Brazilian Food Guide stands out because it is an appropriate instrument for the study context. It was recently developed to support and encourage healthy dietary practices, and to provide information to policies, programs, and actions that aim to incentivize, support, protect, and promote the population's health and food and nutrition security ${ }^{30}$.

This study has some limitations. Its crosssectional design prevents affirming a cause for the outcomes of the established associations because exposure and outcome were assessed simultaneously and so the results should be interpreted with caution.

However, we highlight the importance of this study because according to Magalhães ${ }^{31}$, the construction of new theoretical and methodological approaches for the assessment of public policies and initiatives related to food and nutrition security needs advancement. Additionally, systematic empirical research in the area, combining quantitative and qualitative data stemming from the process of local implementation, allows capturing the complexity of food and nutrition security programs and contributes to effective learning and changes. With respect to soup kitchens, these studies should be coordinated with municipal, state, or district spheres because they are in charge of putting together a technical team to plan, follow, and carry out actions developed in these establishments 5 .

If experience with the assessment of Brazilian programs is small, it is even less significant and systematic than food and nutrition security programs ${ }^{32}$. Food and nutrition security is a field under construction peculiar to the Brazilian context and certainly challenging, whether to the political or scientific sphere. It has been consolidating in the last decades ${ }^{32}$ and is clearly central to the political agenda ${ }^{31}$.

Regarding public data of the Soup Kitchen Program, the reality is no different. The assessment is centralized in the final results of the program ${ }^{33}$. According to data from the Coordenação - Geral de Equipamentos Públicos ${ }^{33}$, the Ministry of Social Development and Fight against Hunger established that one of its goals is to develop a system that continuously monitors and assesses soup kitchens. This is because soup kitchens are an important food and nutrition security policy, and its growth is necessary because the number of establishments is still small for the number of food-insecure Brazilians. At the national and regional levels, the percentage of the population served by the program does not exceed $0.3 \%$ of the target population ${ }^{17}$. Furthermore this policy is integrated with other public policies, such as those that guarantee family farm sustainability ${ }^{30}$, and coordinates with the guideline that promotes an adequate and healthy diet proposed by the new Brazilian Food Guide $^{30}$. 


\section{CONCLUSION}

This study contributed to the identification of the central ideas of social representations of "type of dietary changes that users have made or intend to make" and "difficulties to eat healthier", and revealed the associations between these items and the household food security status of users of soup kitchens in Belo Horizonte.

The similarity of the data regarding the association between the identified social representations and the household food security status evidences the importance of this study for identifying the real need to change dietary habits, in order to better plan, implement, and assess interventions, and to overcome the barriers that prevent these changes.

Moreover, these social representations generally indicate that the subjects are knowledgeable about healthy diet, but they often let common sense guide their practices. Also, the main necessity of these users is not information or knowledge. What they need is educational actions that promote a healthy diet, that fall into the affective learning domain, and that take into account their social representations and socioeconomic conditions. They must also consider the users' values, beliefs, meanings, and senses constructed throughout their lives.

The study of social representations in association with the household food security status is an important element for the success of food and nutrition education interventions, and the methodologies that enable a greater understanding of the determinants of these behaviors are essential to guarantee the effectiveness of actions that promote healthy food habits. Social representations are related to and reflect people's behaviors. Social representations of diet are conditions for food practices. Diet is surrounded by many meanings, from the cultural scope to social experiences, because food practices are not only linked to the need to eat but also pervades cultural identity, social condition, family customs, values, beliefs, time, and the preferred ways of preparing a food.
Additionally, the study results may guide important issues that need to be approached and discussed with soup kitchen users, such as their perceived diet and recognition of their actual food practices. Regarding the socioeconomic profile and household food security status, soup kitchens are an alternative for having a healthy and affordable diet, complying with the proposal of this important public policy which is to preferably serve people who live in large cities and are socially and nutritionally vulnerable.

\section{CONTRIBUTORS}

IC BENTO and FM SOBRINHO collected, analyzed, and interpreted data; created a draft, and reviewed the manuscript. MNS ABREU analysed and interpreted data, and reviewed and approved the final version of the manuscript. MF GAZZINELLI and SCL PEREIRA coordinated and guided study conception and planning, and data analysis and interpretation; and reviewed and approved the final version of the manuscript.

\section{REFERENCES}

1. Shetty P. Nutrition transition and its health outcomes. Indian J Pediatr. 2013; 80(1 Suppl.):21s-7s. http:// dx.doi.org/10.1007/s12098-013-0971-5

2. Gubert MB, Benicio MHD, Santos LMP. Estimativas de insegurança alimentar grave nos municípios Brasileiros. Cad Saúde Pública. 2010; 26(8):1595-605. http://dx.doi.org/10.1590/S0102-311X20100008 00013

3. Instituto Brasileiro de Geografia e Estatística. Pesquisa de orçamentos familiares 2008-2009: despesas, rendimentos e condições de vida. Rio de Janeiro: IBGE; 2010.

4. Brasil. Presidência da República. Decreto-Lei $n^{\circ}$ 11.346, de 15 de setembro de 2006. Cria o Sistema Nacional de Segurança Alimentar e Nutricional Sisan com vistas em assegurar o direito humano à alimentação adequada e dá outras providências. [2015 maio 25]. Disponível em: http://www4. planalto.gov.br/consea/conferencia/documentos/ lei-de-seguranca-alimentar-e-nutricional.

5. Brasil. Ministério do Desenvolvimento Social e Combate à Fome. Programa Restaurante Popular. Brasília: Ministério do Desenvolvimento Social e Com- 
bate à Fome; 2004 [2015 maio 25]. Disponível em http://www.ieham.org/html/docs/manual_ programa_restaurantes_populares.pdf

6. Boog MCF. Educação em nutrição: integrando experiências. Campinas: Komedi; 2013.

7. Moscovici S. Representações sociais: investigações em psicologia social. 6ª ed. Petrópolis: Vozes; 2009.

8. Programa das Nações Unidas para o Desenvolvimento (PNUD). Atlas do desenvolvimento humano nas regiões metropolitanas brasileiras. Brasília: PNUD; 2010 [2015 jun 20]. Disponível em: http:// pnud.org.br/IDH/IDHM.aspx? indiceAccordion= O\&li=li_IDHM

9. Belo Horizonte. Estatística e mapas: exclusão social 2000. Índice de vulnerabilidade social. 2012 [2015 maio 25]. http://portalpbh.pbh.gov.br/pbh/ecp/ contents.do?evento=conteudo\&idConteudo $=19777 \&$ ch $\mathrm{Plc}=19777 \&$ termos $=\mathrm{A}$-indice

10. Babbie E. Survey research methods. $10^{\text {th }}$ ed. Belmont: Wadsworth Publishing; 2004.

11. Brasil. Ministério da Saúde. Conselho Nacional de Saúde. Resolução n 466, de 12 de dezembro de 2012. Diário Oficial da União. 2013; 13 jun, p.59, Seção 1.

12. Associação Nacional de Empresas de Pesquisa. Critério de classificação econômica Brasil: dados com base no levantamento sócio econômico - 2008. São Paulo: Anep; 2010 [2015 maio 25]. Disponível em: www.datavalesp.com.br/CCEB.pdf

13. Ferreira HS, Souza MEDS, Moura FA, Horta BL. Prevalência e fatores associados à Insegurança Alimentar e Nutricional em famílias dos municípios do norte de Alagoas, Brasil, 2010. Ciênc Saúde Colet. 2013; 19(5):1533-42. http://dx.doi.org/10. 1590/1413-81232014195.06122013

14. Lefèvre F, Lefèvre AC. O discurso do sujeito coletivo: um novo enfoque em pesquisa qualitativa (desdobramentos). 2ª ed. Caxias do Sul: Educs; 2005.

15. Amparo LS. Avanços e desdobramentos do marco de referência da educação alimentar e nutricional para políticas públicas no âmbito da universidade e para os aspectos culturais da alimentação. Rev Nutr. 2013; 26(5):595-600. http://dx.doi.org/10. 1590/S1415-52732013000500010

16. Jodelet DP. As representações sociais. Rio de Janeiro: Editora UERJ; 2001.

17. Gonçalves MP, Campos ST, Sarti FM. Políticas públicas de segurança alimentar no Brasil: uma análise do Programa de Restaurantes Populares. Rev Gestão Polit Públicas. 2011 [2015 maio 25]; 1(1):92-111. Disponível em: http://each.uspnet.usp.br/rgpp/ index.php/rgpp/article/viewFile/5/7

18. Levy RB, Claro RM, Mondini L, Sichieri R, Monteiro CA. Distribución regional y socioeconómica de la disponibilidad domiciliaria de alimentos en Brasil, 2008-2009. Rev Saúde Pública. 2012; 46(1):6-15. http://dx.doi.org/10.1590/S0034-89102011 005000088

19. Bento IC. Perfil sociodemográfico, nutricional e psicossocial dos usuários dos restaurantes e refeitório populares de Belo Horizonte - MG: fundamento para a elaboração de uma Intervenção Educativa Alimentar e Nutricional [dissertação]. Belo Horizonte: Universidade Federal de Minas Gerais; 2012.

20. Brasil. Ministério da Saúde. Secretaria de Vigilância em Saúde. Vigitel Brasil 2012: Vigilância de Fatores de Risco e Proteção para Doenças Crônicas por Inquérito Telefônico. Brasília: Ministério da Saúde; 2013.

21. Norcross JC, Krebs PM, Prochaska JO. Stages of change. J Clin Psychol. 2011; 67(2):143-54. http:// dx.doi.org/10.1002/jclp.20758

22. Viegas SMF, Lanza FM, Lara MO, Lage AMD, Penna CMM. Alimentação, uma das chaves para a saúde: análise de conteúdo de reportagens da revista Veja. R Enferm Cent O Min. 2012 [2015 jun 15]; 2(1):78-92. Disponível em: http://www.seer.ufsj.edu.br/index. php/recom/article/view/178/267

23. Silva CL, Costa THM. Barreiras e facilitadores do consumo de frutas e hortaliças em adultos de Brasília. Sci Med. 2013; 23(2):68-74. Disponível em: http://revistaseletronicas.pucrs.br/ojs/index.php/ scientiamedica/article/viewFile/13047/9667

24. Lo YT, Chang YH, Lee MS, Wahlqvist ML. Dietary diversity and food expenditure as indicators of food security in older Taiwanese. Appetite. 2012; 58(1):180-7. http://dx.doi.org/10.1016/j.appet. 2011.09.023

25. Mohammadi F, Harrison GG, Ghazi-Tabatabaei M, Abdollahi M, Houshiar-Rad A, Mehrabi Y, et al. Is household food insecurity associated with overweight/obesity in women? Iran J Public Health. 2013; 42(4):380-90.

26. Willows N, Veugelers $P$, Raine K, Kuhle S. Associations between household food insecurity and health outcomes in the Aboriginal population (excluding reserves). Health Reports. 2011; 22(2):15-20.

27. Marin-Leon L, Francisco PMSB, Segall-Corrêa AM, Panigassi G. Bens de consumo e insegurança alimentar: diferenças de gênero, cor de pele autorreferida e condição socioeconômica. Rev Bras Epidemiol. 2011; 14(3):398-410. http://dx.doi.org/10.1590/ S1415-790X2011000300005

28. Miller CL, Bangsberg DR, Tuller DM, Senkungu J, Kawuma A, Frongillo EA, et al. Food insecurity and sexual risk in an HIV endemic community in Uganda. 
Aids Behav. 2011; 15(7):1512-9. http://dx.doi.org/ 10.1007/s10461-010-9693-0

29. Kepple AW, Segall-Corrêa AM. Conceituando e medindo a segurança alimentar e nutricional. Ciênc Saúde Colet. 2011; 16(1):187-99. http://dx.doi.org/ 10.1590/S1413-81232011000100022

30. Brasil. Ministério da Saúde. Secretaria de Atenção à Saúde. Guia alimentar para a população brasileira. $2^{\mathrm{a}}$ ed. Brasília: Ministério da Saúde; 2014.

31. Magalhães R. Avaliação de políticas e iniciativas públicas de segurança alimentar e nutricional: dilemas e perspectivas metodológicas. Ciênc Saúde Colet. 2014; 19(5):1339-46. http://dx.doi.org/10. 1590/1413-81232014195.12202013
32. Santos SMC, Santos LMP. Avaliação de políticas públicas de segurança alimentar e combate à fome no período de 1995-2002: abordagem metodológica. Cad Saúde Pública. 2007; 23(5):1029-40. http://dx.doi.org/10.1590/S0102-311X20070 00500005

33. Brasil. Ministério do Desenvolvimento Social e Combate à Fome; Secretaria de Avaliação e Gestão da Informação. Rede de equipamentos públicos de alimentação e nutrição: resultados de avaliações. Cad Estud Desenvol Social Debate. 2010; (14):164.

Received: October 31, 2014

Final version: September 21, 2015 Approved: October 13, 2015 